DE DE GRUYTER OPEN
Journal of Intercultural Management

Vol. 6, No. 4, December 2014, pp. 113-131

DOI 10.2478/joim-2014-0039

Jakub Bielikowski

Społeczna Akademia Nauk

\title{
Women in the IT Management - Analysis Dimensions
}

\begin{abstract}
This paper looks into statistics, classic and modern research of women in the management and of women in Information and Computer Technology (ICT) industry. The subject of women in the management, the effect on the companies and their culture and factors underlying women's management success has been raised in the 70's, but there was not much research into the ICT industry until 90's, with quite significant literature in the subject in the last decade. Based on the literature and current management thinking review paper aims to indentify the factors that influence first women choice of ICT as business career and second - women success in the management. The objective is to identify a framework that will be used as a reference in author's qualitative research into woman in the ICT management in different cultures.
\end{abstract}

Key Words: Women career, gender equality in management, women in management, women in ICT

\section{Introduction}

The objective of this paper is to propose a framework for analyzing issues affecting women career in the Information Technology (IT) sector. IT sector belongs to one of the fastest-growing industries/services worldwide. IT sales are reaching the level of approx $\$ 4$ trillion and it is estimated that IT will generate $1.7 \mathrm{M}$ new jobs [Tandon et all, 2012]. Even in crisis-hit Europe IT jobs are set for 5\% growth [European Commission, 2010]. In Poland IT sector sales tripled in last decade to PLN 31bn and IT is expected to grow by 7\% annually [Antal, 2013] - at a rate more than double that of the economy growth. With such a growth rate the IT sector is believed to be a major source for new jobs and management careers.

In his more than 20 years professional IT experience, author noted significant differences between countries in IT women's engagement particularly in manage-

* jakub.bielikowski@gmail.com 
rial roles, underlined by statistically very different levels of women's IT participation (por. Fig. 1). Whereas the subject of women in the management is well researched, the specifics of women in IT (or ICT - Information and Communication Technology sector) management is relatively new, e.g. even simple Google Scholar phrase search brings 9 results for "women in IT management" vs. 24,000 results for "women in management" and "women in ICT" brings just over 900 results.

Researching the high differences in women's IT participation, particularly in senior professional and managerial roles can bring multi-cultural insight into specific organizational and management aspects -organization culture and policies, work conditions, skills and job roles - much beyond state policy issues usually brought to the focus. Those were already noted by Galpin [2002], Huyer et all [2005] and Trauth et all [2008]. Therefore the article looks into proposing a framework for analyzing issues related to women in IT management. The framework is based on analysis of academic research, management consulting reports and industry press publications in both women's vocational choice in IT and women career progress. The article is divided into the following chapters:

1. Women in the management worldwide - current state of women's progress in the management ranks and insight into changing research view on the situation.

2. Women in the IT industry - current state of women's presence in the ICT industry.

3. Framework for women success in the IT management - which pulls together theory to propose classification of factors affecting women IT choice and factors affecting their managerial career.

4. Conclusions - summary of findings.

5. Proposed next research steps - author plans for the framework use.

\section{Women in the management worldwide}

Growth of female's job market participation and increased number of women making into management caused ,women in the management" to became subject of academic and management research. The US women job market share grew from $29 \%$ in 50's [Sloane College, 2009], 38\% in the 70's [United States Department of Labor, 2014], to 46\% from 90's until today [Catalyst, 2014]. In Poland in the 60's women already represented $44 \%$ of all employed [Velkoff, 1995], same as today, with employment rate (percentage of women in employment) remaining around $57.5 \%$ [Główny Urząd Statystyczny, 2012]. That rate is actually below EU average $62.6 \%$, the US rate of $65.4 \%$ and approx. $77 \%$ in Sweden [Eurostat, 2014]. Iceland has one of the highest women employment rates, with $79.5 \%$ of females in the employment [Eurostat, 2014]. In Turkey, the woman's share of labor force is still very low at 29\% [Turkish Statistical Institute, 2012]. While women employment was growing rapidly, historically there were practically no female managers. In the 
US only in 1964 the Civil Rights Act forbade discrimination on the basis of sex as well as race in hiring, promoting, and firing [Congress of the United States, 1964], followed by government actions [National Archives, 2014]. Even if, as late as in the 70 's, in the US females were $38 \%$ of the labor force, they occupied only $15.9 \%$ of managerial position. But, today they fill $51.4 \%$ of the management, professionals and related occupations [Catalyst, 2013].

Similarly to labor force participation women management progression differs significantly by countries. In table below we look at developing and developed countries. In Europe author compares Northern with Southern Europe and all that with Poland as an example for EU Enlargement economy. The purpose is not to identify any statistically valid trends, but rather to find examples of opposite situation:

Table 1 - Women in the management worldwide

\begin{tabular}{|c|c|c|c|c|c|}
\hline Country & $\begin{array}{c}\% \text { of Women } \\
\text { in employ- } \\
\text { ment }\end{array}$ & $\begin{array}{c}\% \text { of Men } \\
\text { in employ- } \\
\text { ment }\end{array}$ & \begin{tabular}{|c|} 
Women \\
among pro- \\
fessional \& \\
technical \\
workers
\end{tabular} & $\begin{array}{c}\text { Women in } \\
\text { the mana- } \\
\text { gement }\end{array}$ & $\begin{array}{c}\text { Women on } \\
\text { boards of li- } \\
\text { sted compa- } \\
\text { nies }\end{array}$ \\
\hline US & $64.5 \%$ & $77 \%$ & $55 \%$ & $43 \%-51.4 \%$ & $10 \%$ \\
\hline Canada & $74 \%$ & $81 \%$ & $56 \%$ & $37 \%-35.7 \%$ & $6 \%$ \\
\hline France & $65.6 \%$ & $73.7 \%$ & $47 \%$ & $39 \%-41.3 \%$ & $18 \%$ \\
\hline Sweden & $77.2 \%$ & $82.2 \%$ & $51 \%$ & $32 \%$ & $17 \%$ \\
\hline Netherlands & $71.6 \%$ & $81.3 \%$ & $50 \%$ & $29 \%-27 \%{ }^{1}$ & $5 \%$ \\
\hline Italy & $49.9 \%$ & $69.8 \%$ & $47 \%$ & $33 \%$ & $8 \%$ \\
\hline Greece & $43.3 \%{ }^{2}$ & $62.7 \%$ & $51 \%$ & $28 \%$ & $11 \%$ \\
\hline Poland & $57.6 \%$ & $72.1 \%$ & $60 \%$ & $36 \%$ & $7 \%$ \\
\hline Germany & $72.3 \%^{3}$ & $81.9 \%$ & $52 \%$ & $30 \%$ & $3 \%$ \\
\hline UK & $69.4 \%$ & $80.5 \%$ & $48 \%$ & $35 \%$ & $7 \%$ \\
\hline Australia & $70 \%$ & $83 \%$ & $54 \%$ & $37 \%$ & $7 \%$ \\
\hline Singapore & $63 \%$ & $83 \%$ & $45 \%$ & $31 \%$ & $\mathrm{~N} / \mathrm{A}$ \\
\hline Thailand & $70 \%$ & $85 \%$ & $56 \%$ & $24 \%$ & $\mathrm{~N} / \mathrm{A}$ \\
\hline Brazil & $65 \%$ & $85 \%$ & $52 \%$ & $36 \%$ & $9 \%$ \\
\hline Qatar & $53 \%$ & $96 \%$ & $20 \%$ & $7 \%$ & $0 \%$ \\
\hline Turkey & $31.8 \%$ & \begin{tabular}{|l}
$75.3 \%$ \\
\end{tabular} & $36 \%$ & $10 \%$ & $8 \%$ \\
\hline
\end{tabular}

${ }^{1}$ Increase from 15\% in 1992 [Davidson, Burke, 2011]

${ }^{2}$ Decrease from $52.9 \%$ in pre-crisis time [Eurostat, 2014]

${ }^{3}$ Increase from $63.1 \%$ in 2005 [Eurostat, 2014]

Source: Own Analysis based on [Eurostat, 2014], [World Economic Forum, 2013], [Catalyst, 2014], [Davidson, Burke, 2011] 
Women's share of top management roles remains in single digits, even in Sweden - advanced equal opportunity country - it is below $20 \%$. Norway is an exception, having $37 \%$ of board seats in listed companies filled by women [WEF, 2013] driven by $40 \%$ quota stipulated by Companies Act amendment in 2003 [Teigen, 2008]. Korn/Ferry Institute [Orr, 2013] identified factors, mostly perceptional, inhibiting women progress to the executive/board level:

1. „Women lag men in the accumulation of high-visibility experiences that prepare them for executive positions.

2. Women are held to higher standards and they are meeting or exceeding them in many areas.

3. Women are rated lower in financial and strategic skills, both of which are mission critical at the executive level."

In this article we concentrate on barriers and enablers of women's managerial progress irrespective of the rank, but the factors above, play important role in today's women careers.

In the 70's the barriers and enables of woman career were looked at from corporate perspective by Wood [1976] pointing that women do face same issues of being a manager as men, but at the same time they face unique constrain of holding a position long considered „man's job” and thus experience insecurity in the managerial job, especially low self-perception. Also they are being perceived as having „demanding nature at times, less flexible” and displaying „unwillingness to reach out and help other females" thus themselves creating barrier for other women.

Kanter [1977] pointed to special status of women in the management - women becoming „tokens: symbols how-women-can-do, stand-ins for all women”. In the absence of external pressure such tokenism was consider a , self-perpetuating mechanism preventing women from organizational success".

In the 80's Schwartz [1986] argued that they are two factors influencing women careers - maternity and different traditions and expectations from sexes, that in turn lead to higher cost of women as manager, views shared in business even today [Morgan, 2012]. Those thesis were developed by Schwartz [1992] and Catalyst Research she founded. Catalyst is now considered an influential player in promoting women in business. This ,gender-centered approach" [Akpinar-Sposito, 2013] with examples like Pringle \& Gold [1990] pointed to different strategies adopted by women at work with ,women becoming more like men” by „understanding of mentoring, power negotiations, managing conflict and change", at the same time looking at affirmative action. However, affirmative actions were not necessarily providing for change of women perception or even made situation worse [Heilman, 1997]. Later research started to question the "gender-centered approach" [Hall-Taylor, 1997], [Bell, Nkomo, 1992] for ignoring increased workplace gender diversity and for promoting treatment that leads to marginalization of women in 
the management. However, radical feminism still brings valuable insight into the management sciences [Sułkowski, 2007].

The increase of women managers is driven by perceived company performance impact, shown by studies conducted by McKinsey [Desvaux, Devillard-Hoellinger, Baumgarten, 2007], Credit Suisse Research Institute [2012] and by formal policies for woman inclusion like Norway, Spain and France setting quota: „to reserve at least 40 percent of their boardroom positions for women within six years" [Reuters, 2011]. Those changes generated new focus at more organizational and competence aspects of women's management careers. In their compilation Billimoria and Piderit [2007] grouped the factor influencing women success in temporary business hierarchy into 3 broad categories:

1. Social factors that affect perception of women ability to succeed in the business like myths and stereotypes in media or the issue of social identity

2. Work-life choices faced by women - especially issue of balancing career with family life, but also work focus and criteria for success

3. Organization factors affecting women in business -leadership style or any formal barriers.

Similar factor were noted in management consulting research: McKinsey [Barsh, Yee, 2012], [Devillard, et all, 2012], [Sussmuth-Dyckerhoff et all, 2012], PDI Nitnth House [2012] or Korn-Ferry [Orr, 2013] expanded on factors like: commitment to company policy for women equality, personal leadership qualities for woman or seeking high-exposure position and personal drivers at work. The 2007 McKinsey report [Desvaux et all, 2007] pointed to education, as engineering and management are two areas, where proper early advice and education access can help to battle low number of female job applicants, and similarly ,to change binary perception of "men's jobs" and "women's jobs" at the very early stage of education".

\section{Women in the IT industry worldwide}

The IT industry has been regarded for long time as men domain, even the own industry publication states that IT is ,a juvenile "boys club", where everything from hardware to source control is pelted with unfortunate, vaguely sexual names. If nothing else, sheer numbers indicate the obvious fact that IT is still a male-dominated field" [Gray, 2013]. Such perception is confirmed by hard statistical numbers: 
${ }^{1}$ Figure 1 Women in ICT in selected countries.

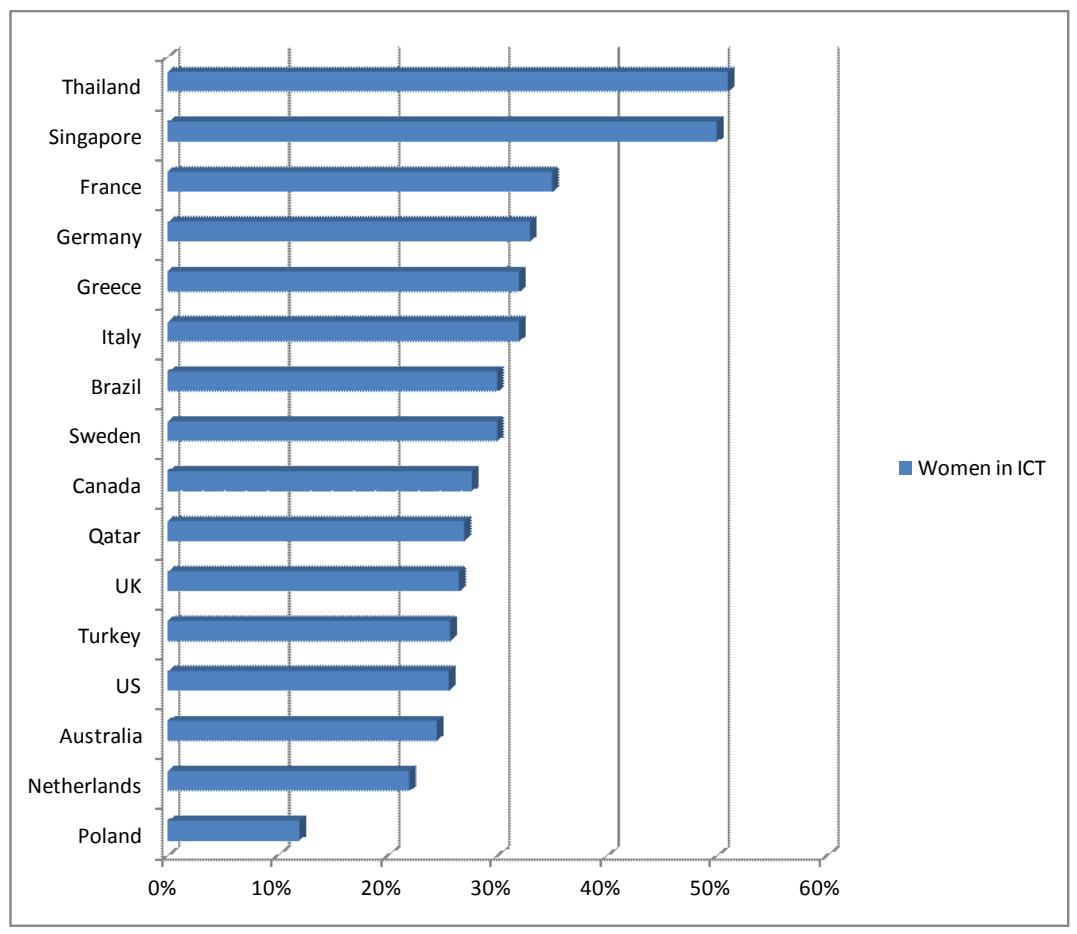

Source: Own analysis, based on [Eurostat, 2014]; [Catalyst, 2014] (US, Canada); [Antal, 2013] (Poland); [Aradi, Schwalje, 2013] (Qatar); [Cash, 2014] (Australia); [Castle, 2014], [Chan, 2006], [Galpin, 2002], (Thailand, Singapore, Brazil)

Women's participation numbers presented on the figure have high degree of uncertainty, particularly true in Poland, where some research [Antal, 2012], [Hozer, Koćmiel, 2008] suggest that $10-15 \%$ is the more accurate figure (or even $9 \%$ being percentage of developers heralded by news [PulsHR, 2014]) rather than 38\% claimed by Eurostat [2014].

IT industry still attracts lower percentage of women then other industries and from career perspective represent „leaky pipeline” [Gras-Velazquez et all, 2009]i.e. loosing women with each step of career progression. More than $56 \%$ of women drop out from IT industry mid-career [Stanford, 2012]. IT industry should be fertile ground for women advancement. ITU - International Telecommunication Union, UN specialized agency - claims for „A bright future in ICT opportunities for a new generation of women" [Tandon at all, 2012]. Even though women ratio

1 This quite impressive number represents share of Qatari women against total of Qatari women and men in the ICT industry, in fact because of large number of Indian immigrant workers (predominantly male) the real share is much lower 
is falling quickly with hierarchy, in the US 15.6\% share [Catalyst, 2013] of board directors in the IT exceeds 10\% ratio for other listed companies. The next chapter looks for factors that influence women's success in IT.

\section{Framework for Women Success in the IT Management}

\section{There are two types of issues that influence women success in the IT ma-} nagement - industry ability to attract and retain women and women's issues related to management progression, as they apply in the IT.

The tables below summarize main factors influencing women IT selection and advancement. Coming from Holland research into vocational choice [Holland, 1959] developments by Krumboltz [1976] and his associates [Mitchell et all, 1996] and summarized by e.g. Curry \& Milsom [2013] the main attention is paid to: a) individual personality and organization fit for that personality, b) support given to the individual from organization, c) job availability, d) perceived employment attractiveness, e) ability to obtain required skills (education), f) suitability of the job offered to personal circumstances.

Author's intention is to propose a framework that joins both formal academic research, management applied research (management \& HR consulting reports) and industry popular publications that were considered to anchor the research with market perceptions and realities.

Table 2 - Factors influencing Vocational IT choice

\begin{tabular}{|c|c|c|}
\hline Factor & Influence & Comment \\
\hline \multicolumn{3}{|c|}{ Economic \& External Factors Influencing IT Choice \& IT Job for Women } \\
\hline $\begin{array}{l}\text { (c) Job } \\
\text { availability - } \\
\text { Global skills } \\
\text { shortage in } \\
\text { IT /Enabler/ }\end{array}$ & $\begin{array}{l}\text { IT faces skill shortage in almost every country [Euro- } \\
\text { pean Commission Information Society and Media, 2010], } \\
\text { [Tandon et all, 2012] making any qualified candidates } \\
\text { interesting. } \\
\text { The campaigns like UK Women for Information Tech- } \\
\text { nology [Mahony, Van Toen, 1990] were specifically tar- } \\
\text { geting women to alleviate skills shortage problem. }\end{array}$ & \\
\hline $\begin{array}{l}\text { (d) Perceived } \\
\text { employment } \\
\text { attractiveness } \\
\text { - Economic } \\
\text { attractiveness } \\
\text { for IT indus- } \\
\text { try / Enabler/ }\end{array}$ & $\begin{array}{l}\text { IT industry is deemed to be one of fastest-growing in the } \\
\text { world [Tandon et all, 2012] and mostly jobs are readily } \\
\text { available there, even in crisis situation }{ }^{1} \text { [Tandon et all, } \\
\text { 2012]. } \\
\text { IT sector is generally better paying than rest of the } \\
\text { economy and in particular in developing countries the } \\
\text { initial salary can be 10x national average [Morgan, 2012], } \\
\text { whereas in Poland it is approx 1.5-2x increasing with } \\
\text { experience to 5-10x [Antal, 2012] and in the US staff } \\
\text { salaries are approx. 2-3x median wage [Computerworld, } \\
\text { 2012] }\end{array}$ & $\begin{array}{l}\text { Economic attractive- } \\
\text { ness works for both } \\
\text { men and women }\end{array}$ \\
\hline
\end{tabular}




\begin{tabular}{|c|c|c|}
\hline Factor & Influence & Comment \\
\hline $\begin{array}{l}\text { (f) Suitability } \\
\text { of the job to } \\
\text { personal situ- } \\
\text { ation - Work } \\
\text { conditions in } \\
\text { the IT / Bar- } \\
\text { rier/ }\end{array}$ & $\begin{array}{l}\text { IT industry does not have „, heavy, dirty and involving } \\
\text { machinery”[Ismail, 2003], [UNESCO] conditions of } \\
\text { other engineering branches, but on the other hand it has } \\
\text { long hours [Tandon et all, 2012] [Morgan, 2012], [Küskü } \\
\text { et all, 2007], [Catalyst, 2003], [Liu, Wilson, 2001] and } \\
\text { „workaholic culture” [Huyer et all, 2005] that may put } \\
\text { women off. } \\
\text { Real flexible hours and the ability to telecommute and } \\
\text { use of IT tools as upcoming trend can make those work } \\
\text { conditions less onerous [Tandon et all, 2012] [Morgan, } \\
\text { 2012] [Catalyst, 2003] }\end{array}$ & $\begin{array}{l}\text { The work conditions } \\
\text { have also influence on } \\
\text { balancing work and } \\
\text { family issue }\end{array}$ \\
\hline $\begin{array}{l}\text { (e) Abil- } \\
\text { ity to obtain } \\
\text { required } \\
\text { qualifica- } \\
\text { tion - Women } \\
\text { educational } \\
\text { orientation } \\
\text { for IT / Bar- } \\
\text { rier/ }\end{array}$ & $\begin{array}{l}\text { Desvaux et all [2007] pointed to crucial lack of IT ori- } \\
\text { entation for girls, where Mahony and van Toen [1990] } \\
\text { pointed that girls are much more attracted to computer } \\
\text { science if education emphasis is on social, business and } \\
\text { communications aspects of computing. Otherwise IT is } \\
\text { perceived as „not applicable to live” [UNESCO] and „IT } \\
\text { workplaces (are not) potentially enabling of cool and con- } \\
\text { nected working lives” [Gras-Velazquez et all, 2009] so as } \\
\text { a consequence IT is seen as not relevant. } \\
\text { UNESCO [UNESCO] and Dryburgh [2000] calls even } \\
\text { for use of gender-sensitive teaching methods or gender } \\
\text { segregation in IT education and ITU for reassessment of } \\
\text { education [Tandon et all, 2012] shared with industry view } \\
\text { [Parsons, 2013]. Hafkin \& Huyer [2007] pointed to the } \\
\text { fact that girls education in IT is often rudimentary and } \\
\text { not enough for advanced jobs. } \\
\text { In } 2003 \text { women comprised only 27\% Computer Science } \\
\text { Graduates in the US, decrease from 37\% in mid-80's } \\
\text { [Catalyst, 2003]. The proper educational preparation is } \\
\text { deemed necessary for many jobs in the industry, though } \\
\text { Hewlett and Sherbin [2014] argue that women education } \\
\text { share is now closer to par (41\%), but the dropout rate is a } \\
\text { problem. }\end{array}$ & $\begin{array}{l}\text { Some countries like } \\
\text { Korea introduced } \\
\text { wide-ranging educa- } \\
\text { tional reform for that } \\
\text { purpose [Lee, 2010] }\end{array}$ \\
\hline
\end{tabular}




\begin{tabular}{|c|c|c|}
\hline Factor & Influence & Comment \\
\hline $\begin{array}{l}\text { (e) Abil- } \\
\text { ity to obtain } \\
\text { required } \\
\text { qualifica- } \\
\text { tion - Women } \\
\text { education in } \\
\text { mathematics } \\
\text { /Barrier or } \\
\text { Enabler/ }\end{array}$ & $\begin{array}{l}\text { Mathematics and other hard science skills are deemed } \\
\text { necessary in IT [Stanford, 2012], though this assertion } \\
\text { is partially being questioned [Mahony, Van Toen, 1990]. } \\
\text { Interest in math/science is often cited by women them- } \\
\text { selves as selection criteria for engineering and IT [Küskü } \\
\text { et all, 2007]. } \\
\text { Initially girls show equal or higher aptitude to mathemat- } \\
\text { ics, but in secondary / tertiary education often boys are } \\
\text { perceived as better in math [Hyde et all, 1990], especially } \\
\text { when results are combined with gender-aptitude pre- } \\
\text { conception [Schmader, 2001]. However more research } \\
\text { under Hyde showed that those are moderated in coun- } \\
\text { tries where women presence in science and politics is } \\
\text { more visible [Else-Quest, Hyde, Linn, 2010]. Therefore } \\
\text { the attitude, rather than absolute skill level may be more } \\
\text { of the problem. }\end{array}$ & $\begin{array}{l}\text { In Turkey it is ob- } \\
\text { served that on second- } \\
\text { ary education show } \\
\text { strong math skills - } \\
\text { that may suggest dif- } \\
\text { ferences in education } \\
\text { system encouraging } \\
\text { girls to learn math }\end{array}$ \\
\hline $\begin{array}{l}\text { (b) Support } \\
\text { given to the } \\
\text { individual } \\
\text { from organi- } \\
\text { zation - "Cost } \\
\text { to employ } \\
\text { women" / } \\
\text { Barrier/ }\end{array}$ & $\begin{array}{l}\text { There is a perception that women are „more expensive } \\
\text { to employ” [Schwartz, 1986], also in IT [Morgan, 2012]. } \\
\text { Factors cited included maternity leave, more require- } \\
\text { ments for flexible / shorter working time or risk of ab- } \\
\text { sence because of child sickness [Maguire, Kleiner, 1993]. } \\
\text { There is still a gender pay gap in the core IT, in Europe } \\
\text { around 15-18\% [European Commission Information } \\
\text { Society and Media, 2010]. The difference in the US is } \\
\text { around 10\% [Frost \& Sullivan, 2013], [Dice, 2013], which } \\
\text { arguably compensates for any additional cost, especially } \\
\text { given higher women's education level [Frost \& Sullivan, } \\
\text { 2013]. } \\
\text { In the age of global IT capabilities limitation [UNESCO] } \\
\text { alternatives like hiring immigrants are no better econom- } \\
\text { ically, because of the global IT salaries pressure. } \\
\text { State regulation requiring women parity on the job, or } \\
\text { regulation rebalancing „,risk of leave” like obligatory } \\
\text { paternity leave, mandatory flexible hours, or even mili- } \\
\text { tary service, in those countries where they apply, remove } \\
\text { perceived cost barrier efficiently }\end{array}$ & $\begin{array}{l}\text { It is interesting } \\
\text { whether IT companies } \\
\text { behave differently in } \\
\text { countries where anti- } \\
\text { discriminatory laws } \\
\text { and special paternity } \\
\text { laws (like mandatory } \\
\text { paternal leave) exists }\end{array}$ \\
\hline \multicolumn{3}{|c|}{ Societal \& Cultural Factors Influencing IT Choice \& Job Retention for Women } \\
\hline
\end{tabular}




\begin{tabular}{|c|c|c|}
\hline Factor & Influence & Comment \\
\hline $\begin{array}{l}\text { (b) Support } \\
\text { given to } \\
\text { the indi- } \\
\text { vidual from } \\
\text { organiza- } \\
\text { tion - Men's } \\
\text { perception } \\
\text { of women's } \\
\text { competence } \\
\text { in IT / Bar- } \\
\text { rier/ }\end{array}$ & $\begin{array}{l}\text { There is lot of stereotyping of women having lower engi- } \\
\text { neering skills that men - as perceived by men themselves } \\
\text { [Küskü et all, 2007] and same applies in IT [Morgan, } \\
\text { 2012], [Gras-Velazquez et all, 2009], [Catalyst, 2003], } \\
\text { [Liu, Wilson, 2001. That makes hiring and promotion } \\
\text { selection in the industry to favor men over women. } \\
\text { Impact of „hiding” sex information on women accep- } \\
\text { tance was shown in music industry with big advance- } \\
\text { ment of women in orchestras after introduction of blind } \\
\text { auction [Credit Suisse, 2012], same is noted for Turkish } \\
\text { anonymized exam systems that promotes women in } \\
\text { engineering [Küskü et all, 2007] }\end{array}$ & \\
\hline $\begin{array}{l}\text { (d) Perceived } \\
\text { employment } \\
\text { attractiveness } \\
\text { - Lack of role } \\
\text { models / Bar- } \\
\text { rier/ }\end{array}$ & $\begin{array}{l}\text { Lack of role models for women in IT [UNESCO] [Par- } \\
\text { sons, 2013] influences men selection criteria as above. } \\
\text { Interestingly successful IT women can see themselves as } \\
\text { experts not as women-experts [Stanford, 2012], so it does } \\
\text { not help women's expertise perception. }\end{array}$ & $\begin{array}{l}\text { Groups such as } \\
\text { She++ [Stanford] } \\
\text { or Black Girls Code } \\
\text { [Parsons, 2013] or } \\
\text { Polish Geek Girls } \\
\text { Carrots do play a role } \\
\text { of helping women to } \\
\text { build awareness of } \\
\text { female capabilities in } \\
\text { the IT industry - as } \\
\text { those have to be first } \\
\text { advertised by women } \\
\text { to be noted. } \\
\end{array}$ \\
\hline $\begin{array}{l}\text { (b) Support } \\
\text { given to the } \\
\text { individual } \\
\text { from or- } \\
\text { ganization } \\
\text { - Number of } \\
\text { women in } \\
\text { IT - "token" } \\
\text { situation / } \\
\text { Barrier/ }\end{array}$ & $\begin{array}{l}\text { “Token” [Kanter, 1976] situation of women in engineer- } \\
\text { ing \& IT positions is common [Evetts, 1997], [Küskü, } \\
\text { 2007] [Standford, 2012] } \\
\text { That has a danger of cornering women into specific im- } \\
\text { age and roles [Stanford, 2012] as self-perpetuating cycle } \\
\text { [Bell, Nkomo, 1992]. }\end{array}$ & $\begin{array}{l}\text { With increase of } \\
\text { women in IT influence } \\
\text { of that factor wears } \\
\text { off. As long as women } \\
\text { are seen as exception, } \\
\text { their presence is not } \\
\text { accepted as rule (e.g. } \\
\text { Polish saying repre- } \\
\text { sents common view } \\
\text { that „exception con- } \\
\text { firms the rule"). }\end{array}$ \\
\hline \multicolumn{3}{|c|}{ Women internal decision factors } \\
\hline $\begin{array}{l}\text { (a) Individual } \\
\text { personal- } \\
\text { ity - Women } \\
\text { interest in IT } \\
\text { /Barrier or } \\
\text { Enabler/ }\end{array}$ & $\begin{array}{l}\text { In line with Holland theory [Holland, 1959] there are } \\
\text { personal capabilities that makes certain women more } \\
\text { interested in engineering careers. In West \& Ross study } \\
\text { [2002] women who choose IT used verbs such as 'fun', } \\
\text { 'exciting' or 'variability of applications' and display real } \\
\text { interest in IT. Despite innate (in this case personal) fac- } \\
\text { tors, building new perception of IT for women is cited } \\
\text { as requisite to attract more women to the IT [Gras- } \\
\text { Velazquez et all, 2009]. }\end{array}$ & \\
\hline
\end{tabular}




\begin{tabular}{|c|c|c|}
\hline Factor & Influence & Comment \\
\hline $\begin{array}{l}\text { (f) Suitability } \\
\text { of the job to } \\
\text { personal } \\
\text { situation - IT } \\
\text { perception as } \\
\text { "boys club" / } \\
\text { Barrier/ }\end{array}$ & $\begin{array}{l}\text { From early days of computer games and computer clubs } \\
\text { IT has a distinctive male image [Mahony, Van Toen, } \\
\text { 1990] with specific subculture. } \\
\text { According to Dryburgh [2000] women already in Com- } \\
\text { puter Science adjust to male culture, but the women } \\
\text { outside are deterred from entering the field. } \\
\text { Women still feel „,marginalized by lab-coat, hard-hat, and } \\
\text { geek workplace cultures that are often exclusionary and } \\
\text { promulgate bias” [Hewlett, Sherbin, 2014] and IT has } \\
\text { „juvenile boys club image” [Grey, 2013] and developer } \\
\text { frequently equals to male [European Commission Infor- } \\
\text { mation Society and Media, 2010]. }\end{array}$ & $\begin{array}{l}\text { See 'Women educa- } \\
\text { tional orientation for } \\
\text { IT' above }\end{array}$ \\
\hline $\begin{array}{l}\text { (a) Individual } \\
\text { personality - } \\
\text { Women self- } \\
\text { perception } \\
\text { of IT skills / } \\
\text { Barrier/ }\end{array}$ & $\begin{array}{l}\text { Though lot of women do believe that men have better } \\
\text { computer skills [Liu, Wilson, 2001] [European Commis- } \\
\text { sion Information Society and Media, 2010] or are afraid } \\
\text { of showing their incompetence [West, Ross, 2002] the } \\
\text { reality is that women who occupy similar IT positions are } \\
\text { often better educated [Frost \& Sullivan, 2013] and their } \\
\text { skill level is at least equal to men's [Gras-Velazquez et all, } \\
\text { 2009], [European Commission Information Society and } \\
\text { Media, 2010]. }\end{array}$ & $\begin{array}{l}\text { This points to more } \\
\text { general issue of } \\
\text { women's perception of } \\
\text { being adequate for job } \\
\text { [Credit Suisse, 2012] }\end{array}$ \\
\hline $\begin{array}{l}\text { (d) Perceived } \\
\text { employment } \\
\text { attractive- } \\
\text { ness - Family } \\
\text { acceptance / } \\
\text { influence / } \\
\text { Enabler/ }\end{array}$ & $\begin{array}{l}\text { For girls having a female family member who works/ } \\
\text { succeeds in engineering/IT is a strong factor to select the } \\
\text { profession [Smith, Dengiz,2009], [Stanford, 2012], simi- } \\
\text { larly to Role Models ability to change industry perception } \\
\text { of women in the IT. Family influence is much stronger } \\
\text { than teacher's influence, even if that is also important } \\
\text { [Dryburgh, 2000] } \\
\text { Also Morgan [2012] and Smith \& Dengiz [2009], [Gras- } \\
\text { Velazquez et all, 2009], [Galpin, 2002] pointed to the } \\
\text { family acceptance of IT/engineering career choice being } \\
\text { an important element. }\end{array}$ & $\begin{array}{l}\text { The family factor is } \\
\text { particularly strong } \\
\text { in cultures with tra- } \\
\text { ditional women role } \\
\text { image }\end{array}$ \\
\hline
\end{tabular}

${ }^{1}$ Example can be article from Academic Job Fairs in Poland's Metro from 7th November 2014 citing full-time opportunities offered to graduates in Signity (IT company) vs part-time in other companies [Metro, 2014]

$$
\text { Source - Own Analysis }
$$


Further the managerial progress is analyzed using factors above, social\& organizational factors identified by Billimoria and Piderit [2007] and recent consulting research like Devillard et all [2012], Orr [2013]: g) social and self-perception of the women's ability to succeed, h) work-life choices, i) organizational factors, j) leadership skills and styles. This is presented in the table below:

Table 3 - Factors influencing managerial progress

\begin{tabular}{|c|c|c|}
\hline Factor & Influence & Comment \\
\hline \multicolumn{3}{|l|}{ Economic factors } \\
\hline $\begin{array}{l}\text { (b) Support given } \\
\text { to the individual } \\
\text { from organiza- } \\
\text { tion - Women } \\
\text { more expensive to } \\
\text { become managers } \\
\text { /Barrier/ }\end{array}$ & $\begin{array}{l}\text { This is already mentioned in Table } 2 \text { above, with particular } \\
\text { fear of promoting women before they get babies, which in } \\
\text { turn could mean wasted investment [Kottis, 1996] like find- } \\
\text { ing replacement, potentially temporary. } \\
\text { There is a significant body of argument [Credit Suisse Re- } \\
\text { search Institute, 2012] that actually having best talent in } \\
\text { the management, independent of gender [Sussmuth-Dyck- } \\
\text { erhoff et all, 2012] is necessity in the age of global talent } \\
\text { scarcity [Desvaux et all, 2007], [Barsh, Yee, 2012] and pro- } \\
\text { vides big economic benefits [Devillard et all, 2013]. }\end{array}$ & \\
\hline \multicolumn{3}{|l|}{ Perception factors } \\
\hline $\begin{array}{l}\text { (g) Social percep- } \\
\text { tion of women's } \\
\text { ability to succeed / } \\
\text { Barrier/ }\end{array}$ & $\begin{array}{l}\text { The general picture of women in society is „submissive, } \\
\text { dependent (...) less competent than men and unsuited for } \\
\text { authority or leadership” [Geis, } 1993 \text { cited in Sanal, 2008] } \\
\text { The successful public figures, which change such model } \\
\text { are cited in research e.g. Davidson \& Burke [2011] to prove } \\
\text { changes in gender perception. }\end{array}$ & \\
\hline $\begin{array}{l}\text { (g) Social percep- } \\
\text { tion of women's } \\
\text { ability to succeed - } \\
\text { Roles stereotyping } \\
\text { /Barrier/ }\end{array}$ & $\begin{array}{l}\text { „The best man for this job is a man” [Maguire, Kleiner, } \\
\text { 1993] assertion was for long a major barrier for women } \\
\text { advancement. } \\
\text { Stereotypes about women may result in perception of e.g. } \\
\text { women unfit for management/ administration jobs [Sanal, } \\
2008] \text {. } \\
\text { Change in perception of a manager's role from the „games- } \\
\text { man” - a self-focused, hypercompetitive and demand- } \\
\text { ing blind obedience, to „paying attention to workforce” } \\
\text { [Stanek, 1980] helped to turn attention to skills where } \\
\text { women perform better [Orr, 2013] like: customer relation- } \\
\text { ship fostering, promoting teamwork, developing talents } \\
\text { and engagement. } \\
\text { On the other hand boxing women as provider of „soft } \\
\text { skills” marginalizes them in the management ranks [Hall- } \\
\text { Taylor, 1997]. } \\
\text { Also it may be observed that women candidates with ap- } \\
\text { propriate education „became not visible” to employers } \\
\text { [Kotti, 1996] who complain about lack of job candidates. } \\
\text { There is a significant move to recognize that old managerial } \\
\text { role stereotype is no longer valid, but there is still a tenden- } \\
\text { cy to prefer being managed by man rather than woman, by } \\
\text { both sexes, independent of actual assessment of managerial } \\
\text { capabilities [Wojciszke, 2002]. }\end{array}$ & \\
\hline
\end{tabular}




\begin{tabular}{|c|c|c|}
\hline Factor & Influence & Comment \\
\hline $\begin{array}{l}\text { (g) Social percep- } \\
\text { tion of women's } \\
\text { ability to succeed } \\
\text { - Role modeling / } \\
\text { Barrier/ }\end{array}$ & $\begin{array}{l}\text { Similarly to the IT role models, in the management role } \\
\text { models act in two ways - to prove that women can do the } \\
\text { job and give women evidence that such progress is possible } \\
\text { [Maguire, Kleiner, 1993] } \\
\text { Women ,lack role models, networks and mentors" [Cata- } \\
\text { lyst, 2003], but also women tend not to advocate their own } \\
\text { success [Devillard et all, 2012], [Orr, 2013] thus even if suc- } \\
\text { cessful are not visible as role models. Therefore promotion } \\
\text { of such role models by Catalyst and likes is important. }\end{array}$ & \\
\hline \multicolumn{3}{|c|}{ Work-life choices for women } \\
\hline $\begin{array}{l}\text { (h) Work-life } \\
\text { choices - Balancing } \\
\text { work and family / } \\
\text { Barrier/ }\end{array}$ & $\begin{array}{l}\text { Practically all texts on women career touch upon issue of } \\
\text { balancing work with having family. Even some research } \\
\text { suggest that among successful women there is dispro- } \\
\text { portionally big share of childless women [Desvaux et all, } \\
\text { 2007]. Mostly because ,anytime, anywhere” availability } \\
\text { that requires sacrifices in family life [Devillard et all, 2013]. } \\
\text { Interesting remark to the issue is shown by Morgan [2012] } \\
\text { where ICT organizations talk ,a lot about supporting wom- } \\
\text { en's family responsibilities (...) but little about men's role } \\
\text { as fathers" as childcare is assumed to be primary women } \\
\text { responsibility. }\end{array}$ & \\
\hline $\begin{array}{l}\text { (h) Work-life } \\
\text { choices - Different } \\
\text { career priorities / } \\
\text { Barrier/ }\end{array}$ & $\begin{array}{l}\text { There is a notion that women lives do not fit male career } \\
\text { development theories [Bell, Nkomo, 1992], [O'Connor, } \\
\text { 2001] and despite slow formal progress, women can get } \\
\text { nonetheless job satisfaction and meaningful development. } \\
\text { Barsh \& Yee [2012] confirmed that women may opt out } \\
\text { from promotion seeking other gratification like giving } \\
\text { people purpose and interacting with them. }\end{array}$ & \\
\hline
\end{tabular}

$$
\text { Source - Own Analysis }
$$

\section{Conclusions}

Women career in the IT can be defined in two critical dimensions:

1. vocational choice - women willingness and ability to enter IT career

2. and factors influencing women managerial progression, which also apply to the IT industry.

Based on the analysis of literature materials, author proposes a framework that analyses factors influencing women career in the IT sector alongside those two dimensions as follows:

1. Vocational IT choice: a) individual personality and organization fit for that personality, b) support given to the individual from organization, c) job availability, d) perceived employment attractiveness, e) ability to obtain required skills (education), f) suitability of the job offered to personal circumstances 
2. Managerial career - the factors defined above and g) social and self-perception of the women's ability to succeed, h) work-life choices, i) organizational factors, j) leadership skills and styles.

The above defined factors form the framework of reference that can help in finding to what extent they are reflected in women's experience in real world. Also that could help to validate recommendations to increase women's IT participation proposed by numerous policy reports like e.g. ITU [Tandon et all, 2012].

The framework requires further consolidation to remove duplicated areas, which at the moment represent different viewpoint (e.g. industry vs. individual or industry vs. broader society) on the same issue. Such clarification should be really performed after the feedback from women in the IT industry, which can help clarify whether the framework's building blocks represent the same or different issue.

\section{Proposed next research steps}

The trends identified above from research and popular literature should be confronted with real women experience in the IT. Such research already commenced by the author and is now planned to be extended to larger women representation in Turkey, Sweden and Poland - as they represent three different economic and management patterns: Sweden - and equal opportunity country with women's IT participation close to $30 \%$ and high management participation, Turkey - country where western stereotypes will not expect significant female IT presence, but is on par with that of the US, and Poland - where women's share of IT jobs was historically very low, but seems to be rapidly changing. Author proposes qualitative research to reflect on perceptions and feelings of people in real management and professional roles in ICT organizations.

\section{Bibliography}

Antal International (2013) IT@PL: Rynek,pracy IT w Polsce, report for Polska Agencja Informacji i Inwestycji Zagranicznych, Maj 2013

Akpinar-Sposito, C. (2013) Women in Management Researcb: Theoretical Perspectives, in 4eme Franco-Tchèque Trends in International Business, Lyon

Aradi, W. and Schwalje W. (2013) Women Wanted, Attracting women to technical fields in Qatar, Qatar Today, October 2013 (http://www.slideshare.net/wesleyschwalje/women-wantedattracting-women-to-technical-fields-in-qatar)

Barsh, J. and Yee, L. (2012) Unlocking the full potential of women at work, McKinsey report, accessed from www.mckinsey.com

Bell, E. and Nkomo, S. (1992) Women in Management Researcb: Towards a New Framework, Alfred P. Sloan School of Management Working Paper no. 3464-92, Massachusetts Institute of Technology, Cambridge MT

Billimoria, D. and Piderit, S.K. (2007) Handbook on Women in Business and Management, Edward Elgar Publishing Limited, Glos, United Kingdom p. 1-11 
Castle, D. (2014) Towards Gender Parity in Asian Science \& Tech, AsianScientis, accessed from http://www.asianscientist.com/2014/06/features/gender-parity-asian-sciencetech-2014/

Cash, M. (2014) Business And Professional Women Australia, speech of Minister Assisting the Prime Minister for Women on Women and Work Forum, 19 August 2014, Perth, downloaded from http://minister.women.gov.au/media/2014-08-19/business-and-professional-women-australia-women-and-work-forum-19-august-2014-perth on 14 October 2014

Catalyst (2003) Bit by Bit: Catalyst Guide to Advancing Women in High Tech Companies, Catalyst report sponsored by Microsoft, Dell, IBM Corporation, Intel, Publication Code D57

Catalyst (2013) US Women in Business, downloaded from: http://www.catalyst.org/knowledge/us-women-business on 12 Oct 2013

Catalyst (2013) Women in the management in the United States, 1960-present, downloaded from http://www.catalyst.org/knowledge/women-management-united-states-1960-present on 12 Oct 2013

Catalyst (2014) Women in High Tech, Globally, downloaded from http://www.catalyst.org/ knowledge/women-high-tech-globally on 12 October 2014

Chan, I. (2006) Is Asia's IT industry male-dominated?, ZDNet, downloaded from http://www. zdnet.com/is-asias-it-industry-male-dominated-2039350680/ on 14 Oct 2014

Computerworld (2012) IT Salary Survey: Staff and Entry-Level Positions, Computerworld, accessed from http://www.computerworld.com/salarysurvey/breakdown/2012/joblevel/3

Credit Suisse Research Institute, (2012) Gender Diversity and Corporate Performance, downloaded from https://publications.credit-suisse.com/tasks/render/file/index. cfm?fileid=88EC32A9-83E8-EB92-9D5A40FF69E66808 on 12 Oct 2013

Curry, J. and Milsom, A. (2013) Career Counseling in P-12 Schools, Springer, New York, p. 247

Davidson, M. and Burke, R. (2011) Women in Management Worldwide: Progress and Prospects - An Overview, in Davidson, M. Burke, R. ed. Women in Management Worldwide: Progress and Prospects, second edition, Gower, Franham, pp. 1-18

Desvaux, G., Devillard-Hoellinger, S. and Baumgarten P. (2007) Women Matter - Gender diversity, a corporate performance driver, McKinsey report, accessed from www.mckinsey.com

Devillard, S., Graven W. and Lawson, E. (2012) Women Matter - Making the Breakthorugh, McKinsey Women Matter 2012 report, accessed from www.mckinsey.com

Devillard, S., Sancier, S., Werner, C., Maller, I. and Kossoff, C. (2013) Gender diversity in top management: Moving corporate culture, moving boundaries, McKinsey Women Matter 2013 report, accessed from www.mckinsey.com

Dice (2013) 2012-2013 Salary Survey, Dice report summary on http://media.dice.com/report/spotlight-on-women-in-tech-3/

Dryburgh, H. (2000) Underrepresentation of girls and women in computer science: classification of 1990s research, Journal of Educational Computing Research, Vol.23, No. 2, p. 181-202

Eagly, A., Johannesen-Schmidt, M. and Van Engen, M. (2003) Transformational, Transactional and Laissez-Faire Leadership Styles: A Meta-Analysis Comparing Women and Men, Psychological Bulletin, Vol. 129, No. 4 pp. 569-591 
Eighty Eight Congress of the United States (1964) Civil Rights Act of 1964, Public Law 88352, Washington, downloaded from http://research.archives.gov/description/299891 on 06 October 2014.

Else-Quest, N., Hyde, J.S. and Linn, M. (2010) Cross-National Patterns of Gender Differences in Mathematics: A Meta-Analysis, Psychological Bulletin, Vol. 136, No. 1, p. 103-127

European Commission Information Society and Media (2010) Women and ICT Status Report 2009, downloaded from http://www.womenandtechnology.eu/digitalcity/servlet/PublishedFileServlet/AAABINHR/women_ict_report.pdf on 10 Sep 2013

Eurostat (2014), Employment Rate by Sex, from LFS main indicators, tsdec420, downloaded from http://epp.eurostat.ec.europa.eu/portal/page/portal/statistics/search_database on 06 October 2014

Evetts, J. (1997) Women and careers in engineering: management changes in the work organization, Women In Management Review, Vol. 12 No. 6, p. 228-233

Galpin, V. (2002) Women in computing around the world, ACM SIGCSE Bulletin - Women and Computing. Volume 34, Issue 2, June 2002, p. 94-100.

Geis, F. L. (1993) 'Self-fulfilling prophecies. A social psychological view of gender', in A. E. Beall and R.J. Stemberg (Eds.), The Psychology of Gender. Guilford Press: New York.

Główny Urząd Statystyczny (2012), Kobiety i mę̇czyźni na rynku pracy, Warszawa

Gras-Velazquez, A., Joyce, A. and Derby, M. (2009) Why girls are still not attracted to ICT studies and careers? European Schoolnet, Brussels

Gray, P. (2013) Does IT have a problem with women? Tech Republic, Downloaded from: http://www.techrepublic.com/blog/tech-manager/does-it-have-a-problem-withwomen/8257?tag=nl.e101\&s_cid=e101\&ttag=e101

Hafkin N. and Huyer, S. (2007) Women and Gender in ICT Statistics and Indicators for Development, Information Technologies and International Development, Vol. 4 No. 2, pp. 25-41

Hall-Taylor, B. (1997) The construction of women's management skills and the marginalization of women in senior management Women In Management Review, Vol. 12 Iss: 7 pp. 255 - 263

Heilman, M. (1997) Sex Discrimination and the Affirmative Action Remedy: The Role of Sex Stereotypes, Journal of Business Ethics, Vol. 16, pp. 877-889

Hewlett, A. and Sherbin, L. (2014) Engineering and Technology Athena Factor 2.0: Accelerating Female Talent in Science, , Center for Talent Innovation report, New York

Holland, J. L. (1959) A theory of vocational choice, Journal of Counseling Psychology, Vol. 6 No. 1 , pp. 35-44

Holland, J. L. (1963) Explorations of theory of vocational choice and achievement: II. A four year prediction study, Psychological Reports, Vol. 12, pp. 547-594

Hozer-Kocmiel, M. and Zimoch, U. (2012). Statistical Portrait of Women in ICT in BSR Countries, Winnet8 Research and Development publication. downloaded from http://www.winnet8. eu, 10 April 2013: Winnet8 Research and Documents

Huyer, S., Hafkin, N., Ertl, H. and Dryburgh, H. (2005) 'Women in the Information Society', chapter 6 in G. Sciades (ed.) From the Digitial Divide to Digital Opportunities: Measuring In- 
fostates for Development, Orbicom, Montreal, downloaded from http://orbicom.ca/upload/ files/research_projects/2005_wis_en.pdf

Hyde, J. S., Fennema E. and Lamon, J. S. (1990) Gender differences in mathematics performance: A meta-analysis, Psychological Bulletin, Vol. 107, pp. 139-155

Ismail, M. (2003) Men and women engineers in a large industrial organization: interpretation of career progression based on subjective career experience, Women in Management Review, Vol.18, Issue 1/2, pp. 60-67

Kanter, R. M. (1977) Men and Woman of the Corporation, Basic Books, p. 206-244 (in 1993 edition)

Kottis, A. P. (1996) Women in management and the glass ceiling in Greece: an empirical investigation, Women in Management Review, Vol. 11 No. 2, pp. 30-38

Krumboltz, J. D., Mitchell, A. and Jones, B. (1976) A social learning theory of career selection, The Counseling Psychologist, Vol. 6, No. 1, p. 71-81

Küskü, F., Özbilgin, M. and Özkale, L. (2007) Against the Tide: Gender Prejudice and Disadvantage in Engineering, Gender, Work and Organization, Vol. 12 No. 2

Lee, K-J-B. (2010) Women in Science, Engineering and Technology (SET) in Korea: Improving Retention and Building Capacity, International Journal of Gender, Science and Technology, 2010, Vol. 2. No. 2

Liu, J. and Wilson, D. (2001) Developing women in a digital world, Women In Management Review, Vol. 16, No. 8, pp. 405-416

Maguire, T. and Kleiner, B. H. (1993) Formal and Informal Organisational Barriers to Women and How to Overcome Them, Equal Opportunities International, Vol. 12, No. 5, pp. $22-25$

Mahony, K. and Van Toen, B. (1990) Mathematical Formalism as a Means of Occupational Closure in Computing - Why "Hard" Computing Tends to Exclude Women, Gender and Education, Vol. 2, No. 3 pp. 319-31

Metro (2014) Bezjezyków nie ma etatu, issue of $7^{\text {th }}$ November 2014, Warsaw

Mitchell, L. K. and Krumboltz, J. D. (1996) Krumboltz's Learning Theory of Career Choice and Counseling, In Career Choice and Development. 3rd ed. Edited by D. Brown, L. Brooks, and associates, Jossey-Bass, San Francisco: p.p. 233-80

Morgan, S. (2012) Women in ICT Sector in Developing Countries: Dualism of Rhetoric vs. Reality in the Case of Sri Lanka, Centre for Development Informatics Working Paper, University of Manchester, Manchester, UK

O'Connor, V. (2001) Women and men in senior management - a "different needs" hypothesis, Women in Management Review, Vol. 16 , No. 8, pp. 400-404

OECD (2011) OECD Guide to Measuring Information Society 2011, OECD publication, accessed from browse.oecdbookshop.org/oecd/pdfs/free/9311021e.pdf

Orr, J. (2013) Career Playbook, Practical tips for women in leadership, Korn/Ferry Institute, downloaded from http://www.kornferryinstitute.com/sites/all/files//documents/briefingsmagazine-download/Career\%20Playbook_Women\%20in\%20Leadership.pdf 
Parsons, R. (2013) Number of ICT women "woeful" globally and in Africa, IT News Africa interview, published 10 June 2013, accessed from http://www.itnewsafrica.com/2013/06/ number-of-women-in-ict-woeful-globally-and-in-africa/

PDI Ninth House (2012) Can Women Executives Break Glass Ceiling? Leadership Research Report, Personnel Decision International Corporation, accessed from http://www.kornferryinstitute.com/reports-insights/can-women-executives-break-glass-ceiling

PulsHR (2014), Kobiety nie poradzq sobie w branży IT? To tylko stereotyp, downloaded from http://www.pulshr.pl/rekrutacja/kobiety-nie-poradza-sobie-w-branzy-it-to-tylko-stereotyp,19105.html

Pringle, J. and Gold, U. (1990) Women in Management: Strategies for Survival or Success?, Women in Management Review, Vol. 5 Iss. 4

Reuters (2013) France set quota for women on big companies' boards, reuters.com, Paris, Thu Jan 13, 2011, 3:44pm EST, accessed from http://www.reuters.com/article/2011/01/13/usfrance-equality-idUSTRE70C5ZA20110113

Sanal, M. (2008), Factors preventing women's advancement in management in Turkey, Education, Vol. 128, No. 3, p. 380-291

Schmader, T. (2002) Gender Identification Moderates Stereotype Threat Effects on Women's Math Performance, Journal of Experimental and Social Psychology, Vol. 38, p. 194-201

Schwartz, F. N. (1992) Breaking with Tradition: Women and Work: The New Facts of Life. New York: Warner

Smith, A. and Dengiz, B. (2010) Women in engineering in Turkey - a large scale quantitative and qualitative examination, European Journal of Engineering Education, Volume 35, Issue 1

South Seattle College (2013), Women Labor History Timeline, downloaded from http://georgetown.southseattle.edu/documents/LERC/Womens\%20Labor\%20History\%20Timeline $\% 20$ for $\% 20$ Website.pdf

Sułkowski, Ł. (2007). Awangarda feministyczna w naukach o zarządzaniu-refleksje maskulinistyczne. Wspótcz̧esne Zarzqudzanie, (3), 13-21

Stanek, L. W. (1980) Women in management: Can it be a renaissance for everybody?, Management Review, November 1980, p. 44-48

Stanford (2012) Collected Statistics on Women in Technology, She++ team research, downloaded from http://sheplusplus.stanford.edu

Sussmuth-Dyckerhoff, C., Wang, J. and Chen J. (2012) Women Matter: An Asian Perspective, McKinsey Report, accessed from www.mckinsey.com

Tandon, N., Pritchard, S., Savelieva, V., Smith, R. G. and Vogt, E. (2012) A bright future in ICT opportunities for a new generation of women, ITU Telecommunications Development Sector Report, February 2012

Teigen, M. (2008) Norwegian Quota Policies, Institutt for samfunnsforskning, ISF paper 2008: 12

Trauth, E. M., Quesenberry, J. L., \& Huang, H. (2008) A multicultural analysis of factors influencing career choice for women in the information technology workforce, Journal of Global Information Management, Vol. 16, No. 4, p. 1-23 
Turkish Statistical Institute (2012) Women in Statistics 2011, Publication number 3660. CankayaAnkara, Turkey: Turkish Statistical Institute

UNESCO (no publication date) Girls in STEM and ICT Careers: The Path towards Gender Equality, UNCESCO, UN Women, ITU and Microsoft workpaper, accessed from http://www.wileurope.org/Content/documents/news/672/Girls\%20In $\% 20$ STEM $\% 20$ and $\% 20 I C T \% 20$ Careers_WP_FINAL.pdf.pdf.pdf

United States Department of Labor (2014), Civilian Labor Force by Sex 1970-2012, downloaded from http://www.dol.gov/wb/stats/facts_over_time.htm\#wilf on 08 Oct 2014

Velkoff, V. (1995), Women in Poland, US Department of Commerce, Economics and Statistic Administration, Bureau of Statistics

West, M. and Ross, S. (2002) Retaining Females in Computer Ccience: a New Look at a Persistent Problem, Consortium for Computing in Small Colleges paper, downloaded from svn. camrdale.org/school/cmpt891/retaining.pdf on 12 Oct 2014

Wojciszke, B. (2002) Człowiek wśród ludzi: zarys psychologii społecznej, Scholar, Warszawa,

Wood, M. (1976) Women in the management - how it is working out, S.A.M. Advanced Management Journal, Vol 41, Winter 1976, pp. 22-30 